\title{
GENDER DISPARITIES IN POVERTY AMONG SMALLHOLDER LIVESTOCK FARMERS IN SOUTH AFRICA
}

\author{
Maziya, M. ${ }^{1}$ Tirivanhu, P. ${ }^{2}$, Kajombo, R.J. ${ }^{3}$ and Gumede, N.A. ${ }^{4}$
}

Correspondence author: M. Maziya. Email: maziyambongeni@gmail.com

\section{ABSTRACT}

This paper analyses gender disparities in poverty and the determinants of poverty among smallholder communal livestock farmers across five provinces in South Africa. A combination of multi-stage and stratified sampling techniques were used to select 591 farmers across the provinces. The Foster, Greer and Thorbecke (FGT) poverty indices were used to determine the extent and severity of poverty among smallholder livestock farmers. The results of the FGT analysis revealed that poverty is prevalent among smallholder livestock farmers but more pronounced among female-headed households. A binary logit regression was used to determine the predictors of poverty among communal livestock owners. Factors such as level of education, gender of household head, access to markets and extension services reduce the probability of a household becoming poor. Conversely, factors such as household size and access to credit had a negative effect on household well-being. These results highlight the importance of strengthening institutions (extension, livestock farmer organisations and markets) to improve smallholder livestock systems. Further, the study recommends that agricultural extension services should integrate gender mainstreaming in interventions that target smallholder communal livestock farmers, and that rural development projects should focus on interventions that aim at diversifying farm income.

Keywords: Binary logit, FGT poverty index, South Africa

\section{INTRODUCTION}

Poverty reduction and ensuring household food security are important policy goals in developing countries, particularly in sub-Saharan Africa (Sinyolo, Mudhara \& Wale, 2014) where more than half $(58.9 \%)$ of the population live in poverty (Alkire \& Housseini, 2014). In 2015, it was reported that $55.5 \%$ of South Africans were living below the poverty line (Stats SA, 2017). One of the constraints to addressing poverty, however, has nothing to do with government delivery capacity, but rather with policy makers understanding of the nature of poverty they are trying address, as well as the appropriate measures for the different types of poverty or poor people (Aliber, 2003). Poverty eradication efforts in South Africa began

\footnotetext{
${ }^{1} \mathrm{PhD}$ student, Centre for Sustainable Agriculture, Rural Development and Extension, University of the Free State, P.O. Box 339 Bloemfontein, 9300, South Africa. Email: maziyambongeni@ gmail.com, ORCID: 00000001-5374-3260

${ }^{2}$ African Research Fellow, Human Sciences Research Council, Private Bag X41, Pretoria, 0001, South Africa. Tel. 012202 2210. Email: PTirivanhu@ hsrc.ac.za, ORCID: 0000-0001-6486-1684

${ }^{3} \mathrm{PhD}$ student at the University of the Western Cape, Department of sociology and Research Scientist at Africa Health Research Institute (AHRI), Social Science and Research Ethics. Africa Centre Building, via R618 to Hlabisa, Somkhele, P.O Box 198, Mtubatuba, 3935, South Africa. Tel. 035550 7507. Email: ntombizonke.gumede@ahri.org, ORCID: 0000-0003-1834-5405

${ }^{4}$ Economist, Economic Planning and Development (EP\&D), P.O Box 30136, Lilongwe 3, Malawi. Email: rjkajombo@gmail.com
} 
immediately after the attainment of democracy in 1994 (Aliber, 2003). An unstable economy and the continued shedding of jobs in the formal economy have frustrated government efforts to eradicate poverty.

Poverty reduction will require sustained economic growth by developing countries (Perry \& Rich, 2007). Bourguignon (2004) ascertained that a $1 \%$ decrease in poverty can be achieved via a certain growth rate, or by a certain decrease in inequality. This has led to the much-used phrase of 'pro-poor growth', defined simply as 'growth that is good for the poor'. At the same time, poverty reduction is a complex process, with no single 'silver bullet' solution. The complexities include the need for action at many levels, ranging from national-level policies that promote economic growth and equity, down to infrastructure development and technological innovations targeted at the priorities of the rural farmer.

Most of the households located in rural areas are poor because of limited economic activities available in rural areas. Thus, in order to raise rural incomes and improve food security, diversification into livestock and a strategy to increase livestock productivity become essential because most rural households, particularly small farmers, already contribute to their livelihoods by keeping livestock, which mainly consists of cattle (Sikhweni \& Hassa, 2014). Currently, there is an increasing focus on smallholder livestock systems and its potential impact on household food security, human welfare and ultimately social development. For instance, the South African Integrated Sustainable Rural Development Strategy of 2004 identified livestock farming as one of the strategies to alleviate poverty and improve food security in rural South Africa (Musemwa, Chagwiza, Sikuka, Fraser, Chimonyo \& Mzileni, 2007).

Livestock has great significance in the livelihoods of most rural households in developing countries and has played a historical role as a major source of agricultural income for generations. The multiple roles of livestock production include food provision, as a store of wealth, use of animal products and the commercial sale of animals. Livestock is also one of the important options for landless and small-scale farmers and for rural women, who represent $70 \%$ of the world poor (FAO, 2011). In South Africa, livestock is also one of the important livelihood strategies. It is estimated that in 2016, there were 13.57 million cattle, 23.71 million sheep and 5.93 million goats (DAFF, 2016). Smallholder farmers who are mostly located in rural communities own about $40 \%$ of this livestock (DAFF, 2015). Given the large number of livestock that are owned by rural communities, even access and ownership could contribute greatly to food security and poverty reduction. Livestock farming in South Africa is estimated to contribute between $25 \%$ and $30 \%$ each year to the agricultural gross domestic product (GDP) (Musemwa et al., 2007).

Gender equity in the ownership of productive resources such as livestock is considered key in improving agricultural productivity, food security and livelihoods of the rural poor. Ownership of such an important asset is skewed in favour of men. Empowering women with high value assets (such as cattle) has been shown to have positive outcomes, not only for women but also for the entire household (Meinzen-Dick, Johnson, Quisumbing, Njuki, Behrman, Rubin \& Waithanji, 2011). In developing countries, women's asset ownership has proven to increase their role in household decision making, bargaining power, allocation and spending on children's health and education (Njuki \& Mburu, 2013). However, women's access to and ownership of high value assets such as cattle has been limited by historical formulation and implementation of patriarchal laws that limit women asset inheritance (Sinyolo, Sinyolo, 
Mudhara \& Ndinda, 2018). Men's livestock ownership rights are guaranteed by a nearuniversal set of inheritance rules that are gender biased and rooted in local systems (Dahl, 1987). In general, women usually own small stock (sheep, goats and poultry) and men own large stock (cattle). One of the reasons is that livestock ownership patterns are linked to social class, religious systems and paternalistic cultures - this means women have weaker ownership rights than men, especially in times of stress (Gurunga \& Lama, 2008). Rural development strategies that focus on women and assets and other environmental linkages are a step in the right direction because the majority of South African women and children reside in rural areas (Bob, 2008). This also applies to the African continent where more broadly, the majority of African women in rural areas are often impoverished, constitute an important source of the agricultural labour force, and produce $60-80 \%$ of the food consumed by households (FAO, 2011).

While much of the earlier research on rural livestock farming centred on scientific and technical aspects such as disease epidemiology, outbreaks and control, animal movements and transboundary diseases, attention is now increasingly turning to the human and social dimensions of rural livestock production. Studies that have looked on the human and social dimension of livestock farming have primarily focused on the potential benefits of livestock farming and the gendered roles involved thereof (Njuki \& Mburu, 2013). Various studies have also looked on the relationship between gender and poverty in South Africa (Nwosu \& Ndinda, 2018; Posel \& Rogan, 2012; Rogan, 2013). However, there are no studies that have investigated gender disparities in poverty among smallholder livestock farmers in South Africa. This is the major gap in the literature that this paper aims to fill. Against this backdrop, the objective of this paper is to provide a gendered analysis of poverty among smallholder livestock farmers in five provinces in South Africa and to ascertain the determinants of poverty among smallholder livestock farmers. Understanding the level of poverty among rural livestock farmers and women in particular is critical, as it informs policy makers in developing gender-sensitive and more informed programmes to enhance livestock farmers in general and women's welfare in particular (de Brauw, 2015; World Bank, 2012). The remainder of the paper contains three sections. Section two discusses the research methodology, focusing on the description of the study area and analytical methods. The third section discusses the results of the study and the final section presents the conclusion and policy recommendations.

\section{METHODOLOGY}

This study used a combination of multi-stage and stratified sampling techniques. The first stage involved the purposive selection of five provinces in South Africa: Eastern Cape, Free State, North West, KwaZulu-Natal and Mpumalanga. The selected provinces had the highest number of farmers engaged in livestock farming (Stats SA, 2016). A simple random sampling without replacement method was used to select the districts, local municipalities, and the villages in each province. The study focused on livestock farmers owning less than 100 cattle or livestock owners owning a combination of cattle and small stock (goats and sheep). A list of farmers was obtained from Animal Health Technicians (AHT's) of the respective districts within the different provinces. Community leaders and the AHT's facilitated the recruitment of participants and made sure that local women livestock owners were available for interviews. In total, 591 livestock farmers were selected from the five provinces using systematic interval random sampling. Data were collected between August and September 2016 using a pretested 
questionnaire. The questionnaire was administered by a team of experienced enumerators who understood the local languages spoken in the different districts in the provinces.

The questionnaire included information on basic household head characteristics, household assets (including livestock ownership), and household income sources. The questionnaire also included questions on farmers' access to information, training on animal handling and spending on primary animal health care products.

\subsection{Analytical methods}

The study used both descriptive and econometric methods of data analysis. Descriptive analysis for categorical variables was performed using the Chi-Square test and t-test was employed for continuous variables. The FGT poverty indices (Foster, Greer \& Thorbecke, 1984) were also used to assess the incidence, depth and severity of poverty in the study areas. A binary logistic regression identified factors/variables that contribute to household welfare of smallholder livestock farmers.

\subsection{Poverty analysis}

There is a general acceptance that poverty is a multi-dimensional phenomenon, defined and measured in a number of ways, and can be perceived in relative or absolute terms (Barrett, 2005; Kajombo, 2014). Sen (1976) introduced an axiomatically based characterisation of the poor. Since then, several indices of poverty have emerged, including the index proposed by Foster, Greer and Thorbecke (FGT index) (Foster et al., 1984). The index proposed by Foster, Greer and Thorbecke (FGT) introduced an additively decomposable indicator of "aversion of poverty" (Foster et al., 1984). The index implicitly regards misery suffered by the poor depending on the distance between a poor household's actual income and the poverty line, not on the number of households that lie between a given household and the poverty line (Bogale Hagedorn \& Korf, 2005). In essence, the FGT index is based on calculations of poverty measures taking income shortfalls of the poor themselves as weights. Various studies have used the FGT indices to investigate the problem of food poverty as a basic dimension of poverty in Kenya (Greer \& Thorbacke, 1986) and in the context of Bangladesh (Ahmed, Khan \& Sampath, 1991), Indonesia (Ravallion \& Bidani, 1994) and Ethiopia (Bigsten, Kebede, Shimelis \& Taddesse, 2003: Bogale et al., 2005) and South Africa (Baiyegunhi \& Fraser, 2010; Kajombo, 2014; Sinyolo et al., 2014).

Our study adopts the FGT poverty indices to analyse the incidence, depth, and severity of poverty among male and female-headed livestock farmers across the five provinces as below.

$\mathrm{P} \alpha=\frac{1}{n} \sum_{i=1}^{q}\left[\frac{(z-y i)}{z}\right] \alpha$

Where:

$\mathrm{P}_{\alpha}$ is the FGT poverty index

$n$ is the number of sample households

$\mathrm{Y}_{\mathrm{i}}$ is consumption expenditure per adult equivalent of $i^{\text {th }}$ household

$z$ represents the cut-off poverty line

$q$ is the number of households below the poverty line

$\alpha$ is the poverty aversion parameter which takes a value of 0,1 , or 2 .

The FGT poverty measures were calculated using the Distributive Analysis Stata Package (DASP) version 2.3, a Stata file created by Araar and Duclos (2013). The poverty aversion 
parameter is a non-negative parameter indicating the degree of sensitivity of the poverty measure to inequality among the poor. The incidence of poverty (headcount index), estimated when $\alpha=0$, measures the share of smallholder livestock farmers below the poverty line. The poverty depth index (poverty gap), estimated when $\alpha=1$, captures information regarding how far off livestock farmers are from the poverty line. The poverty severity index (poverty gap square), estimated when $\alpha=2$, takes into account not only the distance separating the poor from the poverty line (the poverty gap) but also the inequality among the poor.

\subsection{The dependent variable and empirical model}

Based on the minimum per capita calorie adult equivalent caloric intake, a figure of R714 per adult equivalent per month was used as the poverty line at 2016 prices as recommended by Statistics South Africa (Stats SA, 2017). This study uses the Lower-Bound Poverty Line (LBPL) as it has emerged as the preferred threshold that is commonly used for South Africa's poverty reduction targets outlined in the Medium Term Strategic Framework (MTSF), National Development Plan, and Sustainable Development Goals. The R714 value was estimated to a daily energy requirement of $2200 \mathrm{kcal}$ per capita as recommended by the South African Medical Research Council for a healthy and active life. Some researchers (Bigsten et al., 2003; Bogale et al., 2005) argue that consumption expenditures may be a better indicator of household welfare than income hence this study has adopted this approach. Accordingly, a household is considered poor when the household expenditure is insufficient to meet the food and other basic needs of household members.

The standard tools for assessing the correlates of poverty are multivariate consumption expenditure regressions (World Bank, 2000). These regressions can also estimate the partial correlation coefficients between consumption expenditure per adult equivalent and the included explanatory variables (Bogale, 2011). Binary logic models have been widely used where poverty is considered as a "yes" or "no" decision (Bogale et al., 2005; Kajombo, 2014) as in this paper. In this study, a binary logit regression model was used in order to determine the factors that affect poverty among livestock farmers. Households with consumption expenditure per capita per month below the poverty line were assigned a categorical variable $1\left(\mathrm{C}_{\mathrm{i}}<\mathrm{R} 714\right)$ and those above the poverty line were categorised as non-poor $(0)$. The equation can be expressed as follows:

$\mathrm{Y}_{\mathrm{i}}^{*}=\mathrm{X}_{\mathrm{i}}^{\prime} \beta+\mathrm{u}_{\mathrm{i}}$

Where $\mathrm{Y}_{\mathrm{i}}^{*}$ is the dependent variable that indexes the measure of poverty, $\mathrm{u}_{\mathrm{i}}$ is the error term and $\beta$ is the column vector of parameters to be estimated. Following Bogale et al. (2005) and assuming that the cumulative distribution of $u_{i}$ is logistic, a logit model is employed. Then, in this case, the probability of being poor can be given by:

$\mathrm{P}\left(\mathrm{Y}_{\mathrm{i}}=1\right)=\frac{\exp \left(X^{\prime} \beta\right)}{1+\exp \left(X^{\prime} \beta\right)}$

Following Maddala (1993), if we let $X_{\mathrm{ik}}$ be the $k$ th element of the vector of the independent variable $X_{i}$, and $B_{k}$ be the $k$ th element of $\beta$, then the marginal effect of a particular endogenous variable $\mathrm{X}_{\mathrm{i}}$, is given by the following equation:

$\frac{\partial P(Y i=1)}{\partial X^{\prime} i}=\frac{\exp \left(X^{\prime} \beta\right)}{\left[1+\exp \left(X^{\prime} \beta\right)\right]}$

\subsection{Determinants of poverty among livestock farmers}


Economic theory provides a well-developed framework for studying earnings and income, however, there is no similar theory or guidelines that could guide in the more complicated case of poverty (Bigsten et al., 2003; Bogale, 2011). Hence, in principle, a variety of factors could be considered as important determinants of poverty. The explanatory variables include various proxies for household characteristics (such as age, gender, level of education and employment status). Tropical livestock units, total farm income and value of household assets were included to capture the effect of household wealth. These variables are critical in production as they enable the household to produce a surplus for the market and increase income hence household welfare (Alene, Manyong, Omanya, Mignouna, Bokanga \& Odhiambo, 2008). Farmers' access to extension services and participation in farmer organisations were included as a proxy for institutional support. Transaction costs were captured through variables such as market access. Provincial dummy variables were used to control for the unobserved location-specific effects. The location-specific variables were used to capture differences in household welfare that might have arisen due to infrastructure, remoteness, resource endowment, production potential and livestock farming conditions across the five provinces.

Table 1: Description of variables

\begin{tabular}{|c|c|c|}
\hline Variable name & Variable description & $\begin{array}{l}\text { Expected } \\
\text { sign }\end{array}$ \\
\hline Gender & Gender $($ Male $=1$, Female $=0)$ & $+/-$ \\
\hline Age & Age (Years) & $+/-$ \\
\hline Household size & Number of members in a household & + \\
\hline $\begin{array}{l}\begin{array}{l}\text { Dummy for no formal } \\
\text { education }\end{array} \\
\text { ed no }\end{array}$ & $\begin{array}{l}\text { Education level (No formal schooling=1, } \\
\text { Otherwise) }\end{array}$ & + \\
\hline Dummy for primary education & Education level ( $1=$ Primary, $0=$ Otherwise $)$ & - \\
\hline $\begin{array}{l}\text { Dummy for secondary } \\
\text { education }\end{array}$ & $\begin{array}{l}\text { Education level }(1=\text { Secondary/ tertiary, } \\
\text { Otherwise }=0)\end{array}$ & - \\
\hline Dummy for tertiary education & Education level $($ Tertiary $=1$, Otherwise $=0)$ & - \\
\hline Access to credit & Access to credit $(1=$ yes, $0=$ otherwise $)$ & + \\
\hline Dummy for leased land & Leased land ( $1=$ yes, $0=$ otherwise $)$ & $+/-$ \\
\hline Dummy for communal land & Communal land ( $1=$ yes, $0=$ otherwise $)$ & $+/-$ \\
\hline Livestock size & Tropical livestock units & - \\
\hline Employment & Employed $(1=y e s, 0=$ otherwise $)$ & - \\
\hline Full-time farmer & $\begin{array}{l}\text { Working full time with livestock (1=yes, } \\
0=\text { otherwise) }\end{array}$ & $+/-$ \\
\hline Extension & $\begin{array}{l}\text { Number of extension visits in the past } 12 \\
\text { months }\end{array}$ & - \\
\hline Asset value & Value of household assets ('000 Rands) & - \\
\hline Membership of associations & $\begin{array}{l}\text { Membership in livestock groups (1=yes, } \\
0=\text { otherwise) }\end{array}$ & - \\
\hline Social grants & Access to social grants ( $1=$ yes, $0=$ otherwise $)$ & $+/-$ \\
\hline Access to markets & Access to markets (yes $=1$, no $=0$ ) & - \\
\hline Dummy for KwaZulu-Natal & KwaZulu-Natal (1=yes, $0=$ otherwise) & $+/-$ \\
\hline Dummy for Eastern Cape & Eastern Cape $(1=$ yes, $0=$ otherwise $)$ & $+/-$ \\
\hline Dummy for Free State & Free State $(1=$ yes, $0=$ otherwise $)$ & $+/-$ \\
\hline Dummy for North West & North West ( $1=$ yes, $0=$ otherwise $)$ & $+/-$ \\
\hline Dummy for Mpumalanga & Mpumalanga $(1=$ yes, $0=$ otherwise $)$ & $+/-$ \\
\hline
\end{tabular}




\section{RESULTS AND DISCUSSION}

\subsection{Descriptive analysis}

Tables 2 and 3 present the descriptive statistics of 591 smallholder livestock farmers according to gender. Table 2 shows that the majority $(65 \%)$ of the sampled livestock farmers were men, with only $35 \%$ being women. This was expected because livestock rearing in rural South Africa is considered a man's business, as has been reported by other studies (Musemwa et al., 2007; Oladele, Antwi \& Kalawole, 2013).

Table 2: Comparison of continuous variables between male and female livestock farmers $(\mathrm{N}=591)$

\begin{tabular}{|l|l|l|l|l|l|l|l|}
\hline Variables & $\begin{array}{l}\text { Total } \\
(\mathbf{N = 5 9 1})\end{array}$ & & $\begin{array}{l}\text { Males } \\
(\mathbf{N = 3 8 6 )}\end{array}$ & & $\begin{array}{l}\text { Females } \\
(\mathbf{N = 2 0 5})\end{array}$ & $\begin{array}{l}\text { t- } \\
\text { test }\end{array}$ \\
\hline & Mean & Std. Dev & Mean & Std. Dev & Mean & Std. Dev & \\
\hline Age & 58.08 & 15.50 & 57.92 & 15.84 & 58.40 & 14.87 & 0.72 \\
\hline Household size & 5.10 & 2.93 & 5.11 & 2.80 & 5.07 & 3.18 & 0.87 \\
\hline Livestock size & 9.81 & 14.22 & 10.26 & 16.11 & 8.97 & 9.71 & 0.30 \\
\hline $\begin{array}{l}\text { Asset Value } \\
\text { ('000 Rands) }\end{array}$ & 61573.49 & 96814.98 & 65772.31 & 112854 & 53667.41 & 54555.38 & 0.15 \\
\hline
\end{tabular}

Table 3 shows that women were less likely to be part of livestock associations. This was expected, as this is part of the culture and traditional beliefs in rural areas that women should not be community leaders (Sharaunga \& Mudhara, 2016). This is a cause for concern as membership in farmer organisations enable pooling of resources, sharing of information as well as collective bargaining, thereby increasing participation in input and output markets, and reducing transaction costs. The role of taking cattle to dipping tanks or attending livestock committee meetings is delegated to men and boys possibly because of the gendered nature of livestock farming in rural areas. In communal livestock systems, information is shared during dipping days or in meetings of livestock producer groups, which are always male dominated. Another plausible explanation for the lack of women participation is that women face higher opportunity cost of time because of family responsibilities in addition to farming, reducing their incentives to be involved in livestock associations.

Table 3 shows that men had access to markets more than women. Access to livestock marketing channels was more than 50\% significantly higher for males than females. Market access for smallholder rural farmers is one of the means by which farmers can move from a poverty cycle to an income cycle (Magingxa \& Kamara, 2003). This result underscores the need to make institutions accessible and work for women farmers who in many developing countries constitute the majority of the agricultural workforce.

Table 3 shows that $15 \%$ of the farmers had access to credit and that more men than women were able to obtain credit. It is a widely held view that providing access to credit and savings options may increase the risk-bearing capacity of households. Households with better access to credit will have a greater capacity to absorb risks and to pool these risks across periods thus stabilizing consumption over time (Zeller, Baun, Johm \& Puetz, 1994). The fact that a small proportion of livestock farmers had access to credit is a cause for concern as access to credit for both men and women may enable them to acquire physical capital and promote the 
intensification of livestock production (Pender, Nkonya, Jagger, Sserukuuma \& Ssali, 2003). Table 3 demonstrates that being full time in livestock activities was $50 \%$ significantly higher for males than for females. The results show that more males are employed in off-farm activities than females and this might have a negative bearing on the welfare of women as access to off-farm employment may raise incomes of participating households and consequently improve household welfare.

Table 3: Comparison of categorical variables between male and female livestock farmers (N=591)

\begin{tabular}{|l|l|l|l|l|}
\hline Variables & $\begin{array}{l}\text { Total } \\
\mathbf{N = 5 9 1}\end{array}$ & $\begin{array}{l}\text { Males (\%) } \\
\mathbf{N = 3 8 6}\end{array}$ & $\begin{array}{l}\text { Females (\%) } \\
\mathbf{N = 2 0 5}\end{array}$ & $\mathbf{X}^{\mathbf{2}}$ test \\
\hline $\begin{array}{l}\text { Dummy for no formal } \\
\text { education }\end{array}$ & 33.67 & 35.49 & 30.24 & 0.199 \\
\hline Dummy for primary education & 32.32 & 31.09 & 34.63 & 0.380 \\
\hline $\begin{array}{l}\text { Dummy for secondary } \\
\text { education }\end{array}$ & 30.29 & 29.02 & 32.68 & 0.356 \\
\hline Dummy for tertiary education & 4.91 & 5.18 & 4.39 & 0.672 \\
\hline Full time farmer & 43.49 & 54.15 & 23.41 & $0.000^{* * *}$ \\
\hline Credit access & 14.55 & 17.10 & 9.76 & $\mathbf{0 . 0 5 1 *}$ \\
\hline Formal employment & 6.43 & 7.77 & 3.90 & $0.068^{*}$ \\
\hline Extension access & 37.39 & 40.41 & 31.71 & 0.107 \\
\hline Membership in associations & 39.59 & 45.60 & 28.29 & $0.000^{* * *}$ \\
\hline Social grants & 34.69 & 63.75 & 36.25 & 0.367 \\
\hline Access to markets & 21.15 & 26.17 & 11.71 & $0.000^{* * *}$ \\
\hline
\end{tabular}

Notes: $* * *, * *$, and $*$ means significant at $1 \%, 5 \%$, and $10 \%$ levels, respectively

\subsection{Foster Greer Thorbecke (FGT) poverty indices}

The FGT poverty indices indicated that male livestock farmers were better off than female livestock farmers. Using the 2016 Lower Bound poverty line of R714 per capita per month, Table 4 indicates that the poverty incidence (proportion of smallholder livestock farmers below the poverty line) was higher among women-headed households compared to men-headed households, with $62 \%$ of men classified as poor compared to $74 \%$ of women livestock farmers. Poverty incidence was generally higher among the sampled farmers as $66 \%$ of the farmers were classified as poor. This figure is quite high compared to the national average of 55\% reported by Statistics South Africa (Stats SA, 2017) but similar to the rural national average of $65.4 \%$ reported by the World Bank (2018). The results are also similar to previous studies focusing on smallholder crop producers (Kajombo, 2014; Sinyolo et al., 2014; Sinyolo et al., 2018). The depth and severity of poverty is higher among women than men. The poverty gap index for women is $38 \%$ and $27 \%$ for men. The poverty gap index captures information regarding how far off livestock farmers are from the poverty line. In this case, it implies that current consumption levels of women and male-headed households would have to increase by $38 \%$ and $27 \%$, respectively, to lift them out of poverty. The poverty severity index indicates that inequality among the poor is higher among female-headed households than it is for males. Overall, these results suggest that poverty in South Africa is gendered; females bear a significantly higher burden of poverty than their male counterparts. These results confirm earlier studies that found that female-headed households are more likely to be poor than their male counterparts (Posel \& Rogan, 2012; Rogan, 2013). This is worrying given the rise in the 
proportion of female-headed households in sub-Saharan Africa (SSA) (Madhavan \& Schatz, 2007; Milazzo \& van de Walle, 2017). Some of the reasons for this trend include labour migration by male heads resulting in "left-behind" female heads (mostly spouses of labour migrants).

Table 4: FGT poverty indices according to gender $(\mathrm{N}=591)$

\begin{tabular}{|l|l|l|l|}
\hline FGT index & Pooled sample & Men & Women \\
\hline Poverty headcount index & 0.66 & 0.62 & 0.74 \\
\hline Poverty gap index & 0.31 & 0.27 & 0.38 \\
\hline Poverty severity index & 0.18 & 0.15 & 0.23 \\
\hline
\end{tabular}

Table 5 shows that the highest poverty incidence is in KwaZulu-Natal (78\%) and the lowest poverty incidence is in the North West $(45 \%)$ province. The high poverty incidence in KwaZulu-Natal indicates high deprivation among smallholder livestock farmers in the province. The depth of poverty is the highest in KwaZulu-Natal (41\%), followed by Eastern Cape (35\%) and Mpumalanga (35\%).

Table 5: FGT poverty indices by province $(\mathrm{N}=591)$

\begin{tabular}{|l|l|l|l|}
\hline Province & $\begin{array}{l}\text { Poverty Headcount } \\
\text { index }\end{array}$ & Poverty Gap index & Poverty Severity index \\
\hline Free State & 0.57 & 0.22 & 0.10 \\
\hline Eastern Cape & 0.72 & 0.35 & 0.20 \\
\hline KwaZulu-Natal & 0.78 & 0.41 & 0.25 \\
\hline Mpumalanga & 0.67 & 0.35 & 0.22 \\
\hline North West & 0.45 & 0.10 & 0.04 \\
\hline
\end{tabular}

\subsection{Predictors of poverty among livestock farmers}

The binary logit model was used to determine the household characteristics that contribute significantly to household welfare of smallholder livestock farmers. Table 6 presents the results of the binary logit model. Collectively, Table 6 indicates that all estimated coefficients are statistically significant since the chi-square has a p-value of less than $1 \%$. The pseudo $\mathrm{R}^{2}$ value is 0.495 and is considered relatively good enough for cross-sectional data. The sign of the coefficient in the regression model shows exogenous variables direction of influence on the endogenous variable. It follows that a negative value indicates a decrease in poverty while a positive coefficient implies a likelihood that a household will be poor.

The results indicate that the attainment of tertiary education plays an important role in eradicating poverty. Education reflects the prime role that human capital plays in determining poverty. In fact, these results support a widely held view that education is critical in the fight against poverty. It has important effects on the poor children's chance to escape from poverty in their adult age and plays a catalytic role for those who are most likely to be poor, particularly those households living in rural communities (Bogale et al., 2005). Education implies more opportunities for generating income and a better understanding of technologies aimed at improving livestock productivity (i.e. the use of animal vaccines). This result is consistent with findings from Tekana and Oladele (2011). 
Similarly, the coefficient of formal employment of the household head is negatively related to poverty, implying that households, where the head is employed, are less likely to be poor. This result underscores the importance of off-farm employment. Off-farm income generating activities complement livestock farming by availing the household with additional resources for both consumption and investment. This, in turn, enhances asset accumulation and opens up escape routes out of poverty. Since much of off-farm employment requires educational skills, Bogale (2011) argues that there is a need for government policies to focus on strategies that stimulate low and semi-skilled types of non-farm employment opportunities in rural areas as escape routes out of poverty.

Access to extension services was found to have a negative relationship with poverty. The negative effect of access to extension services may indicate that in the study areas, those households who get technical advice or those who participate in dipping are well aware of the advantage/s of agricultural technologies such as animal vaccines and medicines, adopt new technologies, and improve animal production, thereby improving their household incomes and escaping poverty. This result underscores the importance of extension officers as agents for technology diffusion for improved livelihoods and household welfare. Similarly, in line with expectations, the coefficient for market access is negative and statistically significant implying that livestock farmers who have access to cattle marketing channels are able to beat the poverty trap. However, in South Africa, output markets for smallholder farmers are notably underdeveloped, uncoordinated and lack essential infrastructure (Magingxa \& Kamara, 2003). If improved, these marketing channels such as livestock auctions could significantly reduce rural poverty. The statistical significance of the coefficients of access to markets and extension services underscores the crucial role of institutional arrangements in promoting livestock farming in rural areas.

The coefficient of credit access is statistically significant and positively related to vulnerability to poverty. This implies that households who have access to credit are likely to be poor. This result is not in conformity with the a priori expectation. In normal circumstances, increased access to credit enhances household welfare through the provision of investment credit to boost household income (Adugna \& Heidhues, 2000) as well as smooth consumption (Zeller et al., 1994), which could significantly influence a household's income by helping its members to tap economic opportunities, thereby assisting them to get out of poverty. This result may be an indication that the cost of borrowing for smallholder livestock farmers is high as they often get credit from informal lenders who charge exorbitant interests and struggle to pay back their loans and find themselves in the poverty trap. This finding is consistent with those of Maziya, Mudhara \& Chitja (2017) who found that access to credit had a negative effect on the food security status of smallholder farmers in KwaZulu-Natal. However, this study did not establish how farmers used their credit. If used for consumption rather than livestock production, it explains the negative effect of informal credit on household welfare.

The relationship between household size and poverty is negative and significant. Household size reflects the number of units among which household resources need to be allocated according to the weight of each unit (Bogale, 2011). However, household size may have an ambiguous role in the poverty status of households depending on the relative strength of size economies in consumption as against the diminishing return to scale. The results reveal that a large household size increases the chance of a household becoming poor. An increase in 
household size means more people to feed and, for a fixed income, it indirectly reduces expenditure income per head (Maziya et al., 2017).

Table 6: Logit results for the determinants of household welfare $(\mathrm{N}=591)$

\begin{tabular}{|l|l|l|l|l|}
\hline Variable & Coefficient & & $\begin{array}{l}\text { Marginal } \\
\text { effects }\end{array}$ & \\
\hline & Value & SE & Value & SE \\
\hline Gender & $-0.743^{* *}$ & 0.350 & $-0.046^{* *}$ & 0.021 \\
\hline Age & -0.000 & 0.011 & -0.000 & 0.001 \\
\hline Household size & $0.733^{* * *}$ & 0.159 & $0.049^{* * *}$ & 0.007 \\
\hline Dummy for primary education & -1.044 & 1.529 & -0.084 & 0.148 \\
\hline Dummy for secondary education & -1.603 & 1.550 & -0.147 & 0.191 \\
\hline Dummy for tertiary education & $-2.547^{* *}$ & 1.190 & -0.404 & 0.287 \\
\hline Access to credit & $0.705^{* *}$ & 0.288 & $0.047 * *$ & 0.023 \\
\hline Land tenure_communal & 0.077 & 0.387 & 0.005 & 0.026 \\
\hline Land tenure_leased & -0.395 & 0.840 & -0.031 & 0.078 \\
\hline Livestock size & -0.007 & 0.020 & -0.000 & 0.001 \\
\hline Employment & $-1.268^{*}$ & 0.680 & -0.137 & 0.109 \\
\hline Work full time with livestock & -0.394 & 0.428 & -0.027 & 0.029 \\
\hline Access to extension services & $-0.668^{* *}$ & 0.287 & $-0.045^{* *}$ & 0.023 \\
\hline Asset value & $-0.000^{* * *}$ & $4.13 \mathrm{e}-06$ & $-1.76 \mathrm{e}-06^{* * *}$ & 0.000 \\
\hline Membership of associations & 0.445 & 0.321 & 0.029 & 0.022 \\
\hline Social grants & 0.024 & 0.339 & 0.002 & 0.023 \\
\hline Access to markets & $-0.826^{* *}$ & 0.400 & -0.069 & 0.045 \\
\hline Dummy for KwaZulu-Natal & -0.319 & 0.723 & -0.024 & 0.061 \\
\hline Dummy for Eastern Cape & 0.157 & 0.432 & 0.010 & 0.028 \\
\hline Dummy for North West & -0.134 & 0.539 & -0.009 & 0.040 \\
\hline Dummy for Mpumalanga & -0.282 & 0.506 & -0.020 & 0.039 \\
\hline Constant & 2.539 & 1.847 & & \\
\hline-2 log likelihood & -153.867 & & & \\
\hline Wald chi2(22) & 110.20 & & & \\
\hline Prob > chi2 & $0.000^{* * *}$ & & & \\
\hline Pseudo R ${ }^{2}$ & 0.495 & & & \\
\hline Number of observations & 591 & & & \\
\hline No: & & & \\
\hline
\end{tabular}

Note: $* * *, * *$ and $*$ denote statistical significance at $1 \%, 5 \%$ and $10 \%$ levels, respectively.

The estimated coefficient associated with the gender of the household head is worth mentioning, given the standard presumption. In this case, the results confirm the results of the FGT decomposition that the probability of being poor is higher among females than in males, employing per capita daily food requirements. Nwosu and Ndinda (2018) refer to this predicament facing women as the "feminisation of poverty", a situation where women have a higher incidence of poverty than men; that their poverty is more severe than men; that there is a trend to greater poverty associated with female-headed households. This gender disparity in poverty is worrying given that women in the sample own some form of livestock, which they can convert into cash in time of need. 
The marginal effect of each exogenous variable in the logit model explains the effect on poverty probability of changing a continuous variable by one unit, all other variables held constant. A possible interpretation of the results presented in Table 6 is that, for example, adding one adult equivalent in a household will increase poverty by approximately $5 \%$. Similarly, increasing the credit available to households will increase poverty by $5 \%$.

\section{CONCLUSION AND POLICY IMPLICATIONS}

This study aimed to investigate the gender differences in household poverty and the determinants of poverty among smallholder livestock farmers. The results of the FGT analysis indicated that poverty is more pronounced among women. About $74 \%$ of women farmers were classified as poor compared to $62 \%$ of male farmers. However, it must be highlighted that the incidence of poverty was high among the sampled households. In general, these results suggest that the incidence of poverty among farming households is on the increase and that farming households are more vulnerable to poverty compared to those in the other sector of the economy. The results also indicate that men had more access to extension, credit and markets. Men were also more likely to participate in livestock organisations than women; this has a bearing on women's access to information. This implies that there should be a deliberate policy to ensure equity in access to institutional services as access to these services has the potential to improve productivity and lift households out of poverty.

The results of the binary logit regression indicated that factors such as market access, attainment of tertiary education, and access to extension services have the potential to alleviate poverty in the study areas. Any rural development strategies that enhance the above variables should be strengthened and supported. Overall, what is clear from these findings is that livestock ownership on its own cannot reduce poverty. There is a need to consider other rural micro-projects and development strategies that can enhance off-farm income. The study also recommends that agricultural extension services should integrate gender mainstreaming in interventions that target smallholder livestock farmers in order to realize women's full potential. Extension advisory services should ensure that women are included in livestock associations, such would improve women's access to information and economic empowerment.

\section{REFERENCES}

ADUGNA, T. \& HEIDHUES, F., 2000. Determinants of Farm Households access to Informal Credit in Lume District, Central Ethiopia. Sav. Dev., 24(4): 27- 46.

AHMED, A.U., KHAN, H.A. \& SAMPATH, R.K., 1991. Poverty in Bangladesh: Measurement, Decomposition and Intertemporal Comparison. In: J. Dev. Stud., 27(4): 48-63.

ALENE, A. D., MANYONG, V. M., OMANYA, G., MIGNOUNA, H. D., BOKANGA, M., \& ODHIAMBO, G., 2008. Smallholder market participation under transactions costs: maize supply and fertilizer demand in Kenya. Food Policy. 33(4):318-328.

ALIBER, M., 2003. Chronic poverty in South Africa: Incidence, causes and policies. World. Dev., 31(3):473-490.

ALKIRE, S. \& HOUSSEINI, B., 2014. "Multidimensional Poverty in Sub-Saharan Africa: Levels and Trends." OPHI Working Paper 81, Oxford University.

ARAAR, A. \& DUCLOS, J.Y., 2013. DASP: Distributive Analysis Stata Package. Université Laval PEP, CIRPÉE and World Bank. 
BAIYEGUNHI, L.J.S. \& FRASER, G.C.G., 2010. Determinants of Household Poverty Dynamics in Rural Regions of the Eastern Cape Province, South Africa. Poster presented at the Joint 3rd African Association of Agricultural Economists (AAAE) and 48th Agricultural Economists Association of South Africa (AEASA) Conference, Cape Town, South Africa, September 19-23, 2010.

BARRETT, C.B., 2005. Rural poverty dynamics: development policy implications. Agri. Eco., 32(1): 45-60.

BIGSTEN, A., KEBEDE, B., SHIMELIS, A. \& TADDESSE, M., 2003. Growth and Poverty Reduction in Ethiopia: Evidence from Household Panel Survey. In: World. Dev., 31 (1): 87-106.

BOB, U., 2008. Rural Women's Relations to Land Resources in KwaZulu-Natal: Issues of Access and Control. Alternation 15. (1):110-134.

BOGALE, A. 2011. Analysis of poverty and its covariates among smallholder farmers in the Eastern Hararghe highlands of Ethiopia. J. Dev. Agri. Eco., 3(4): 157-164.

BOGALE, A., HAGEDORN, K. \& KORF, B., 2005. Determinants of poverty in Ethiopia. Quarterly J. Int. Agr., 44(2):101-120.

BOURGUIGNON, F., 2004. The poverty-growth-inequality triangle. Indian Council for Research on International Economic Relations. New Delhi, India.

DAHL, G., 1987. Women in pastoral production. In: Dahl G (Editor). Realm pastor. Women. Ethnos 52, 1-2, 246-280.

DE BRAUW, A., 2015. Gender, control, and crop choice in northern Mozambique. Agri. Eco., 46(3):435-448.

DEPARTMENT OF AGRICULTURE, FISHERIES AND FORESTRY (DAFF), 2011. A profile of the South African beef market value chain. Available from: http://www.daff.gov.za/docs/AMCP/BeefMVCP2010-11.pdf

DEPARTMENT OF AGRICULTURE, FISHERIES AND FORESTRY (DAFF), 2015. A profile of the South African beef market value chain. Available from: http://www.nda.agric.za/doaDev/sideMenu/Marketing/Annual\%20Publications/Com modity\%20Profiles/field\%20crops/Beef\%20market\%20value\%20chain\%20profile\%2 02015.pdf

DEPARTMENT OF AGRICULTURE, FISHERIES AND FORESTRY (DAFF), 2016. Trends in the agricultural sector. Available from https://www.daff.gov.za/Daffweb3/Portals/0/Statistics\%20and\%20Economic\%20Ana lysis/Statistical\%20Information/.Trends\%20in\%20the\%20Agricultural\%20Sector\%20 2016.pdf

FOOD AND AGRICULTURE ORGANISATION (FAO), 2011. The state of food and agriculture: Closing the gender gap for development. Rome, Italy.

FOSTER, J., GREER, J. \& THORBECKE, E., 1984. A Class of Decomposable Poverty Measures. Econometrica. 52 (3): 761-766.

GREER, J. \& THORBECKE, E., 1986. Food Poverty Profile in Applied to Kenyan Smallholders. Eco. Dev. Cul. Cha. 35 (1): 115-141.

GURUNGA, J. \& LAMA, K. 2008. Women Organizing for Change in Agriculture and Natural Resource Management (WOCAN), Ithaca, New York, USA.

KAJOMBO, R.J., 2014. Poverty and food security analysis in KwaZulu-Natal province of South Africa: implications for policy. Unpublished $\mathrm{PhD}$ Thesis, University of KwaZulu-Natal.

MADDALA, G.S., 1993. Limited Dependent and Qualitative Variables in Econometrics. Cambridge University Press. 
MADHAVAN, S. \& SCHATZ, E. J., 2007. Coping with change: Household structure and composition in rural South Africa, 1992-2003. Sca. J. Pub. Hea. 35(69_suppl):85-93.

MAGINGXA, L.L. \& KAMARA, A., 2003. Institutional perspectives of enhancing smallholder market access in South Africa. Contributed Paper Presented at the 41st Annual Conference of the Agricultural Economic Association of South Africa (AEASA), October 2-3, 2003, Pretoria, South Africa.

MAZIYA, M., MUDHARA, M. \& CHITJA, J., 2017. What factors determine household food security among smallholder farmers? Insights from Msinga, KwaZulu-Natal, South Africa. Agrekon. 56(1): 40-52.

MEINZEN-DICK, R., JOHNSON, N, QUISUMBING, A., NJUKI, J., BEHRMAN, J., RUBIN, D. \& WAITHANJI, E., 2011. Gender, Assets, and Agricultural Development Programs: A Conceptual Framework, CAPRi Working Paper No. 99. Washington, DC: International Food Policy Research Institute.

MILAZZO, A. \& VAN DE WALLE, D. 2017. Women Left Behind? Poverty and Headship in Africa. Demography. 54(3):1119-1145.

MMBANDO, F.E., WALE, E.Z. \& BAIYEGUNHI, L.J.S., 2015. Welfare impacts of smallholder farmers' participation in maize and pigeonpea markets in Tanzania. Food Security. 7: 1211-1224.

MUSEMWA, L., CHAGWIZA, C., SIKUKA, W., FRASER, G., CHIMONYO, M., \& MZILENI, N., 2007. Analysis of cattle marketing channels used by small-scale farmers in the Eastern Cape Province, South Africa. Liv, Res. Rur. Dev., 19(9):1-8.

NJUKI, J. \& MBURU, S., 2013. Gender and Ownership of Livestock Assets. A book chapter in J. Njuki and P. Sanginga (eds) (2013) Women, Livestock Ownership and Markets: Bridging the Gender Gap in Eastern and Southern Africa, London: Routledge, pp. 2138.

NWOSU, C.O. \& NDINDA, C., 2018. Gender-based Household Compositional Changes and Implications for Poverty in South Africa. J. Int. Wom. Stud., 19(5): 82-94.

OLADELE, O.I., ANTWI, M.A. \& KALAWOLE, A.E., 2013. Factors influencing the demand for animal health services by livestock farmers along border villages of South Africa and Namibia. Int. J. App. Res. Vet. Med., 11(2):123-129.

PENDER, J., NKONYA, E., JAGGER, P., SSERUKUUMA, D. \& SSALI, H., 2003. Strategies to Increase Agricultural Productivity and Reduce Land Degradation: Evidence from Uganda. Contributed paper selected for presentation at the 25th International Conference of Agricultural Economists, August 16-22, 2003, Durban, South Africa.

PERRY, B.D. \& RICH, K.M., 2007. Poverty impacts of foot-and-mouth disease and the poverty reduction implications of its control. Vet. Rec., 160:238-241.

POSEL, D. \& ROGAN, M., 2012. Gendered trends in poverty in the post-apartheid period, 1997-2006. Dev. Sou. Afr., 29(1):97-113.

QUISUMBING, A. \& PANDOLFELLI, L., 2010. Promising approaches to address the needs of poor female farmers: Resources, constraints and interventions. Wor. Dev., 38(4):581-592.

QUISUMBING, A.R., RUBIN, D., MANFRE, C., WAITHANJI, E., VAN DEN BOLD, M. \& MEINZEN-DICK, R., 2014. Closing the Gender Asset Gap: Learning from Value Chain Development in Africa and Asia. IFPRI Discussion Paper 01321.

RAVALLION, M. \& BIDANI, B., 1994. How Robust Is a Poverty Profile? In: The. Wor. Ban. Eco. Rev., 8 (1):75-102.

ROGAN, M., 2013. Poverty and headship in post-apartheid South Africa, 1997-2006. Soc. Indi. Res., 113(1):491-511. 
SEN, A. 1976. Poverty: An Ordinal Approach to Measurement. In: Econometrica. 44 (2): 219231.

SHARAUNGA, S. \& MUDHARA, M., 2016. Factors influencing water-use security among smallholder irrigating farmers in Msinga, KwaZulu-Natal Province. Water Policy. 18(5): 1209-1228.

SIKHWENI, N.P. \& HASSAN, R., 2014. Determinants of herd size among small-scale cattle farmers: the case of selected villages at the Mhinga Traditional Authority in Limpopo, South Africa. Agrekon. 53(4):106-122.

SINYOLO, S., MUDHARA, M. \& WALE, E., 2014. The impact of smallholder irrigation on household welfare: The case of Tugela Ferry irrigation scheme in KwaZulu-Natal, South Africa. Water SA. 40(1): 145-156.

SINYOLO, S.A., SINYOLO, S., MUDHARA, M. \& NDINDA, C., 2018. Gender Differences in Water Access and Household Welfare among Smallholder Irrigators in Msinga Local Municipality, South Africa. J. Int. Wom. Stud., 19(5): 129-146.

STATISTICS SOUTH AFRICA (STATS SA), 2016. Community Survey 2016: Agricultural households. Statistics South Africa, Pretoria.

STATISTICS SOUTH AFRICA (STATS SA), 2017. Poverty Trends in South Africa: An examination of absolute poverty between 2006 and 2015. Statistics South Africa, Pretoria.

TEKANA, S.S. \& OLADELE, O.I., 2011. Impact analysis of Taung irrigation scheme on household welfare among farmers in North-West province, South Africa. J. Hum. Eco., 361:69-77.

WORLD BANK, 2000. A Sourcebook for poverty reduction strategies. World Bank, Washington DC.

WORLD BANK, 2012. World Development Report 2012: Gender Equality and Development. World Bank, Washington DC.

WORLD BANK, 2018. Overcoming poverty and inequality in South Africa. An Assessment of drivers, constraints and opportunities. World Bank, Washington DC.

ZELLER, M., VON BRAUN, J., JOHM, K. AND PUETZ1, D., 1994. Sources and Terms of Credit for the Rural Poor in the Gambia. Afr. Rev. Mon. Fin. Bank., 1:167 - 186. 